\title{
Digital inclusion and Internet use among older adults in Brazil: a cross-sectional study
}

\author{
Inclusão digital e o uso da internet pela pessoa idosa no Brasil: estudo transversal \\ Inclusión digital y uso de internet por el adulto mayor en Brasil: estudio transversal
}

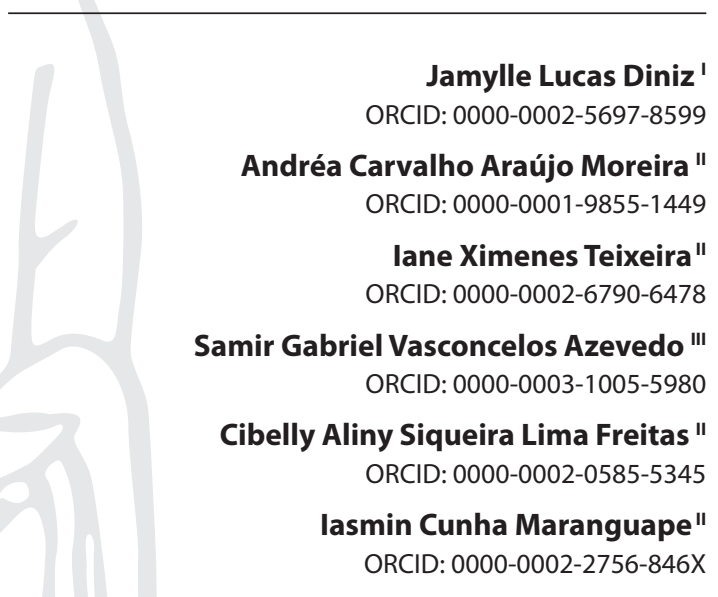

'Universidade Federal do Ceará. Fortaleza, Ceará, Brazil. "Universidade Estadual Vale do Acaraú. Sobral, Ceará, Brazil. "vniversidade Estadual do Ceará. Fortaleza, Ceará, Brazil.

How to cite this article: Diniz JL, Moreira ACA, Teixeira IX, Azevedo SGV, Freitas CASL, Maranguape IC. Digital inclusion and Internet use among older adults in Brazil: a cross-sectional study.

Rev Bras Enferm. 2020;73(Suppl 3):e20200241. doi: http://dx.doi.org/10.1590/0034-7167-2020-0241

\section{Corresponding author:} Jamylle Lucas Diniz E-mail: jamylledz@hotmail.com

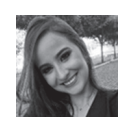

EDITOR IN CHIEF: Antonio José de Almeida Filho ASSOCIATE EDITOR: Fátima Helena Espírito Santo

Submission: 04-03-2020

Approval: 07-27-2020

\begin{abstract}
Objectives: To describe the profile of Brazilian older adults who use the Internet, the means of Internet access and the purpose of Internet use and to verify the existence of association between socio-demographic variables and variables related to Internet use. Method: Cross-sectional study with Brazilian older adults who used the social networks Facebook and WhatsApp. Descriptive, univariate, and bivariate analysis were conducted. Results: 384 older adults participated in the study, mostly women (52.08\%), with a mean age of 64.6 years old and who used the Internet to address health concerns (65.36\%). The main activities on the internet were reading, listening to music, playing games, watching videos and photos (37.30\%). The main benefits pointed out were interaction $(74.5 \%)$, learning $(19.2 \%)$ and entertainment (19.25\%). There were statistically significant differences between time spent online and the variables gender, age, and civil status. Conclusion: This study showed characteristics of older adults who use the Internet and revealed the possibility of using digital technologies to optimize health care for this population.
\end{abstract}

Descriptors: Aged; Internet; Health Promotion; Digital Inclusion; Social Media.

\section{RESUMO}

Objetivos: Descrever o perfil de pessoas idosas brasileiras que utilizam a internet, o meio de acesso e a finalidade desse uso, e verificar a existência de associação entre variáveis sociodemográficas e aquelas relacionadas ao uso da internet. Método: Estudo transversal com idosos brasileiros usuários das redes sociais Facebook e WhatsApp, analisados de modo descritivo, uni e bivariado. Resultados: Participaram 384 idosos, em maioria mulheres (52,08\%), com idade média de 64,6 anos e que utilizavam a internet para sanar dúvidas de saúde $(65,36 \%)$. Principais atividades na internet foram ler, ouvir música, jogar, ver vídeos e fotos (37,30\%). Principais benefícios apontados são interação (74,5\%), aprendizado (19,2\%) e entretenimento $(19,25 \%)$. Houve diferenças estatísticas entre tempo de permanência conectado e variáveis sexo, idade e estado civil. Conclusão: Este estudo mostrou características de idosos que utilizam a internet, algo que desperta para possibilidade do uso de tecnologias digitais na otimização dos cuidados em saúde nessa população.

Descritores: Idoso; Internet; Promoção da Saúde; Inclusão Digital; Mídias Sociais.

\section{RESUMEN}

Objetivos: Describir el perfil de adultos mayores brasileños que utilizan la Internet, los medios de acceso y el propósito de este uso, y comprobar si existen asociaciones entre las variables sociodemográficas y las relacionadas con el uso de la Internet. Método: Se trata de un estudio transversal entre usuarios brasileños de edad avanzada usuarios de las redes sociales Facebook y WhatsApp, analizado de forma descriptiva, univariante y bivariante Resultados: Participaron 384 personas de edad avanzada, en su mayoría mujeres $(52,08 \%)$, con edad media de 64,6 años que utilizaban Internet para resolver dudas sobre salud $(65,36 \%)$. Las actividades practicadas en Internet eran leer, escuchar música, jugar, ver videos y fotos $(37,30 \%)$. Los principales beneficios señalados son la interacción $(74,5 \%)$, el aprendizaje $(19,2 \%)$ y el entretenimiento $(19,25 \%)$. Se encontraron diferencias estadísticas entre el tiempo que permanecían conectados y las variables sexo, edad y estado civil. Conclusión: Este estudio ha demostrado algunas características de adultos mayores que utilizan internet y plantea la posibilidad de utilizar las tecnologías digitales para mejorar los cuidados sanitarios de ese grupo etario.

Descriptores: Adultos Mayores; Internet; Promoción de la Salud; Inclusión Digital; Redes Sociales. 


\section{INTRODUCTION}

With the advance of technological innovations, the Internet has become an essential part of the daily life of almost all individuals. In Brazil, about two thirds of the population (69.8\%) has an Internet connection ${ }^{(1)}$. Similarly, as the number of older adults grows worldwide, the interest of this population in virtual spaces grows $^{(2)}$. In the country, the proportion of older adults who access the Internet has increased from $24.7 \%$, in 2016, to $31.1 \%$, in $2017^{(1)}$.

Yet, this increase is still not enough to remove older adults from the process of "digital exclusion"(3). For many, the virtual environment represents a functional alternative to television or radio, and websites and social networks are attractive for their innovative character and fast access to information ${ }^{(4)}$.

Thus, the Internet is considered a space where older adults can enjoy information related to multiple interests, which involve knowledge, leisure, work, interaction/communication, and especially health benefits ${ }^{(5)}$. Therefore, the digital inclusion of older adults is seen as a way to increase their autonomy and quality of life. Despite the challenges faced by this population when using new technologies, a study reported that older adults are willing to adopt new technologies when their usefulness and usability outweigh feelings of inadequacy ${ }^{(6)}$. Situations like this can be seen when older adults are motivated by the interaction with grandchildren and relatives and feel encouraged to learn and adopt digital technologies.

Thereby, this study aims to identify the most common means of internet access used by Brazilian older adults and the purpose of Internet use, with the objective of supporting the development of health promotion strategies/interventions for this population through the use of digital technologies, as the use of these technologies for this purpose can be extremely broad. In this context, the study contributes to technological, social and gerontological sciences. In particular, we recognize the fundamental role of the nurse in health promotion for older adults, through health education actions within the Brazilian Unified Health System, and the need to use digital technologies to improve their clinical practice, demystifying the idea that older adults are not part of this reality. The combination of education and digital inclusion can support planning and implementation of qualified actions in health promotion ${ }^{(7)}$.

The results of this study may help understanding that the use of the Internet and social media brings several benefits to older adults, improving the quality of life of this population. It is understood that this tool can favor the communication process, foster interpersonal relationships, reduce social isolation, stimulate cognition and increase closeness to friends and relatives, even if there is physical distance. Thus, the study provides multi-professional knowledge, as it will describe how older adults use the Internet.

\section{OBJECTIVE}

Describe the profile of Brazilian older adults who use the Internet, the means of Internet access and the purpose of Internet use. In addition, it sought to verify the existence of an association between socio-demographic variables and variables related to Internet use.

\section{METHODS}

\section{Ethical aspects}

The research respected the ethical and legal recommendations of the Resolution of the National Health Council No. 466/12. The study was appreciated by the Research Ethics Committee of the State University of Vale do Acaraú.

Participants who were interested in collaborating in the research accessed the link published on Facebook and WhatsApp and received an online Informed Consent Form (TCLE). After reading the form, the participant had to choose between the options:"I accept to participate in the research" and "I do not accept to participate in the research". When the older adult selected the option "I accept to participate in the research", they were automatically sent to the data collection instrument; if they chose otherwise, the survey was concluded.

\section{Design, setting and period}

This is a quantitative cross-sectional study. The study was described according to the checklist Strengthening the Reporting of Observational Studies in Epidemiology (STROBE)(8).

The research was carried out through the internet. Data was collected from September to December 2018.

\section{Population and sample; inclusion and exclusion criteria}

The selection of the older adults was carried out using the "snowball sampling" technique, in which the first participants indicate new participants, who also indicate others, and so on, until reaching the proposed goal $\mathrm{I}^{(9)}$. Thus, already knowing about the existence of groups of older adults on Facebook, it was possible to reach the first participants through the identification of 13 groups: Terceira idade, Terceira idade conectada, Longevidade saudável, Portal terceira idade, Núcleo de Apoio à Terceira Idade, Grupo da terceira idade, Renascer da terceira idade, Terceira idade melhor, Integrar terceira idade, Idosos mãos solidárias, Grupo de idosos zuquinha, Grupo de idosos de bem com a vida, Longevidade.

The sample was calculated based on the sample size for a prevalence study design with an infinite population. The parameters were a prevalence of at least $50 \%(p)$ of older adults who use the internet to search for health benefits, level of confidence ( $Z 1-\alpha / 2)$ of $95 \%$ and maximum absolute error $(d)$ of 0.05 . Thus, using the formula (, the sample size was 385 older adults.

Thus, 384 older adults freely participated in the study. Participants met the following inclusion criteria: people aged 60 or over, of both genders, Brazilian, who used the internet through the social networks Facebook and WhatsApp, regardless of frequency of use. Two older adults were excluded for not answering the entire instrument or giving disconnected responses.

The reasons for using these social networks as part of the inclusion criteria for the research participants were: they are free for the user and widely used by the entire population, regardless of the age group; their tools have potential to enhance knowledge and/or learning of certain subjects; the user does not need expertise in creating the space or any training to start activities; and they enable moments of interaction, regardless of the time and space in which individuals are ${ }^{(10)}$. 


\section{Study protocol}

The questionnaire was developed on the Google Forms platform and made available through a link. It included questions related to socio-demographic data (gender, age, place of residence, civil status, level of education and occupation) and to the use of the internet (means of access, time of access, purposes and perceived benefits).

The questionnaire was linked to the account of the main author to ensure the security of the information. The questionnaire was completed from September to December 2018. Data was collected through an online questionnaire made available through a link in the feed of the aforementioned Facebook groups, when allowed by the administrator of each group, or individually on Messenger, or even on WhatsApp, when the contact information of the older adult was available. It should be noted that no data was extracted from these social media.

\section{Analysis of results and statistics}

Data were compiled on Excel, statistically analyzed with the support of the software R for Windows version 3.6.2 and synthesized in tables. The descriptive analysis of the data included the calculation of absolute and relative frequencies. The association between categorical variables and socio-demographic data was analyzed using the Chi-square test for independence or Fisher's exact probability test, according to the expected frequencies of each category. The prevalence ratios and respective $95 \%$ confidence intervals were used to measure the magnitude of the relationship between these categorical variables. In all inferential calculations, the level of significance was set at 0.05 .

The association between the quantitative variable of age and the qualitative variables was verified with the Mann-Whitney test. This is an alternative to the T-test for two independent samples, when the data does not follow a normal distribution. In this study, normality was verified using the Lilliefors test.

\section{RESULTS}

A total of 384 Brazilian older adults who used Facebook and/or WhatsApp participated in the research. The socio-demographic data of the participants are shown in Table 1.

The socio-demographic data of the sample reveals that the female gender was slightly predominant (52.08\%), the mean age was 64.60 years, most participants were married (72.99\%), almost half had completed high school (48.44\%) and $67.61 \%$ were retired. In addition, almost half of the sample lived in the Southeast and Northeast regions ( $23.44 \%$ and $23.18 \%$, respectively).

Table 2 shows results regarding the devices most used by older adults to access the internet, the activities carried out in the virtual environment and the use of internet to obtain information about health care.

There was no statistically significant association between sociodemographic variables and activities carried out on the internet.

Table 3 shows the association between benefits of Internet use, time spent online, daily internet access and the gender variable.

Among the benefits of using the internet pointed out by the participants are interaction, learning and entertainment $(74.5 \%$,
$19.02 \%, 19.02 \%$ respectively). The variables that showed a statistically significant difference according to gender were: updating $(p=0.03)$, entertainment $(p=0.02)$, learning $(p=0.007)$ and time spent online $(p=0.008)$. It was found that not considering updating as a benefit was 33\% more prevalent among female participants ( $P R=0.77-95 \%$ $\mathrm{Cl}$ :0.62-0.95). The benefits of entertainment and learning were more frequent among male participants, with $65 \%$ and $45 \%$, respectively ( $P R=1.65-95 \%$ Cl: 1.05- 2.59; PR=1.45- 95\% Cl: 1.09- 1.94). In addition, spending more than 2 hours on the Internet was $36 \%$ more frequent among women ( $P R=1.36-95 \% \mathrm{Cl}$ : 1.08-1.72).

Table 1 - Socio-demographic profile of Brazilian older adults using social networks, Sobral, Ceará, Brazil, 2019

\begin{tabular}{|c|c|c|}
\hline Variables & $\mathbf{n}$ & $\%$ \\
\hline \multicolumn{3}{|l|}{ 1. Gender } \\
\hline Male & 184 & 47.92 \\
\hline Female & 200 & 52.08 \\
\hline \multicolumn{3}{|l|}{ 2. Age (years) } \\
\hline $60 \mid---63$ years & 142 & 36.80 \\
\hline 63 ---- 66 years & 92 & 23.89 \\
\hline $66 \mid---69$ years & 94 & 24.35 \\
\hline 69 ---- 72 years & 25 & 6.49 \\
\hline 72 ---- 75 years & 20 & 5.19 \\
\hline 75 ---- 78 years & 4 & 1.03 \\
\hline 78 & 1 & 0.25 \\
\hline $81|----| 84$ years & 2 & 0.51 \\
\hline \multicolumn{3}{|l|}{ 3. Region } \\
\hline Central-west & 70 & 18.23 \\
\hline Northeast & 89 & 23.18 \\
\hline North & 55 & 14.32 \\
\hline Southeast & 90 & 23.44 \\
\hline South & 80 & 20.83 \\
\hline \multicolumn{3}{|l|}{ 4. Level of education } \\
\hline Illiterate & 2 & 0.51 \\
\hline Elementary School & 15 & 3.88 \\
\hline High School & 187 & 48.44 \\
\hline University Education & 168 & 43.64 \\
\hline Postgraduate Studies & 12 & 3.11 \\
\hline \multicolumn{3}{|l|}{ 5. Occupation } \\
\hline Working & 123 & 31.86 \\
\hline Retired & 261 & 67.61 \\
\hline \multicolumn{3}{|l|}{ 6. Civil Status } \\
\hline Married & 280 & 73 \\
\hline Divorced & 26 & 6.70 \\
\hline Single & 68 & 17.70 \\
\hline Widowed & 10 & 2.6 \\
\hline
\end{tabular}

Table 2 - Variables related to the devices used in daily life, the activities carried out and the use of the internet to answer questions about health care, Sobral, Ceará, Brazil, 2019

\begin{tabular}{lcc}
\hline Variables & $\mathbf{n}$ & $\%$ \\
\hline 1. Devices used in daily life & & \\
Cellphone & 359 & 93.48 \\
Notebook & 10 & 2.60 \\
Computer & 8 & 2.08 \\
Tablet & 7 & 1.84 \\
2. Activities carried out on the Internet & & \\
Read, listen to music, watch videos and photos, play games & 144 & 37.30 \\
Talk to people & 77 & 19.94 \\
Meet new people and/or seek a romantic relationship & 56 & 14.50 \\
Research and study & 43 & 11.13 \\
Access social networks & 40 & 10.36 \\
Shopping and financial transactions & 17 & 4.40 \\
Working & 7 & 1.81 \\
3. Answer health care questions & & \\
Yes & 251 & 65.36 \\
\hline
\end{tabular}


Table 4 refers to the associations between the region of residence of the older adult and the main means of obtaining information, the most prevalent levels of education, daily internet access and time spent online.

There were statistically significant differences between the regions of Brazil and the factors: main means of obtaining information, television and internet ( $p=0.014)$; the most prevalent levels of education, high school and university $(p=0.001)$; daily Internet access $(p=0,001)$; and time spent online $(p=0.001)$. The media most used by the older adults were the television and the internet $(\mathrm{n}=$ 380). Radio, newspapers, and printed books were also cited.
The television was the preferred source of information among older adults in the Southeast and Center-west, and the Internet was preferred among older adults in the North, Northeast and South. This fact stands out when comparing the level of education, since most older adults in the North and Northeast regions have a secondary level of education. Regarding internet access, almost all older adults in the Northeast and South regions accessed the internet every day, compared to around $85 \%$ in the Southeast and Center-west regions, and only $63.63 \%$ in the North region. In addition, most older adults in the North region did not access the internet for more than two hours a day (16.4\%). The Center-west region presented a similar

Table 3 - Benefits, time spent online and daily internet access for Brazilian older adults by gender. Sobral, Ceará, Brazil, 2019

\begin{tabular}{|c|c|c|c|c|c|c|c|}
\hline & & & & & nvalue* & $\mathbf{P R} * *$ & $95 \% \mathrm{CI}$ \\
\hline & $\mathbf{n}$ & $\%$ & $\mathbf{n}$ & $\%$ & $p$ value & PKn & $95 \%$ \\
\hline 1. Benefits of using th & & & & & & & \\
\hline Updating & & & & & & & \\
\hline Yes & 41 & 20.5 & 56 & 30.43 & 0.03 & 0.77 & $0.62-0.95$ \\
\hline No & 159 & 79.5 & 128 & 69.56 & & & \\
\hline Autonomy and ind & & & & & & & \\
\hline Yes & 16 & 8 & 7 & 3.80 & 0.13 & - & - \\
\hline No & 184 & 92 & 177 & 96.19 & & & \\
\hline Interaction & & & & & & & \\
\hline Yes & 140 & 70 & 137 & 74.45 & 0.39 & - & - \\
\hline No & 60 & 30 & 47 & 25.54 & & & \\
\hline Entertainment & & & & & & & \\
\hline Yes & 32 & 16 & 35 & 19.02 & 0.02 & 1.65 & $1.05-2.59$ \\
\hline No & 168 & 84 & 149 & 80.97 & & & \\
\hline Learning & & & & & & & \\
\hline Yes & 63 & 31.5 & 35 & 19.02 & 0.007 & 1.45 & $1.09-1.94$ \\
\hline No & 137 & 68.5 & 149 & 80.97 & & & \\
\hline None & & & & & & & \\
\hline Yes & 12 & 6 & 20 & 10.86 & 0.12 & - & - \\
\hline No & 188 & 94 & 164 & 89.13 & & & \\
\hline 2. Time spent online & & & & & & & \\
\hline More than 2 hours & 89 & 44.5 & 57 & 30.97 & 0.008 & 1.36 & $1.08-1.72$ \\
\hline Up to 2 hours & 111 & 55.5 & 127 & 69.02 & & & \\
\hline 3. Daily Internet acces & & & & & & & \\
\hline Yes & 178 & 89 & 157 & 85.32 & 0.36 & - & - \\
\hline No & 22 & 11 & 27 & 14.67 & & & \\
\hline 4. Internet access more & & & & & & & \\
\hline Yes & 181 & 90.5 & 166 & 90.21 & 1.00 & - & - \\
\hline No & 19 & 9.5 & 18 & 9.978 & & & \\
\hline
\end{tabular}

Note: *Pearson's Chi-square test; **Prevalence ratio.

Table 4 - Association between the main means of obtaining information, most prevalent levels of education, daily internet access and time spent online and the region of residence of the older adult, Sobral, Ceará, Brazil, 2019

\begin{tabular}{|c|c|c|c|c|c|c|c|}
\hline & $\begin{array}{c}\text { North } \\
\mathbf{n}\end{array}$ & $\begin{array}{c}\text { Northeast } \\
\mathbf{n}\end{array}$ & $\begin{array}{c}\text { Southeast } \\
\mathbf{n}\end{array}$ & $\begin{array}{c}\text { Center-west } \\
\mathbf{n}\end{array}$ & $\begin{array}{c}\text { South } \\
\mathbf{n}\end{array}$ & Total & $p$ value \\
\hline Means of obtaining information & & & & & & & $0.014^{*}$ \\
\hline Television & 24 & 32 & 50 & 41 & 31 & 178 & \\
\hline Internet & 31 & 55 & 38 & 29 & 49 & 202 & \\
\hline Total & 55 & 87 & 88 & 70 & 80 & 380 & \\
\hline Level of education & & & & & & & $<0.001 *$ \\
\hline High School & 50 & 59 & 23 & 30 & 25 & 187 & \\
\hline University education & 5 & 17 & 58 & 38 & 50 & 168 & \\
\hline Total & 55 & 76 & 81 & 68 & 75 & 355 & \\
\hline Daily Internet access & & & & & & & $<0.001 * *$ \\
\hline Yes & 35 & 81 & 78 & 62 & 79 & 335 & \\
\hline No & 20 & 8 & 12 & 8 & 1 & 49 & \\
\hline Total & 55 & 89 & 90 & 70 & 80 & 384 & \\
\hline Time spent online & & & & & & & $<0.001^{* *}$ \\
\hline Up to 2 hours & 46 & 48 & 51 & 52 & 41 & 238 & \\
\hline More than 2 hours & 9 & 41 & 39 & 18 & 39 & 146 & \\
\hline Total & 55 & 89 & 90 & 70 & 80 & 384 & \\
\hline
\end{tabular}

Note: *Pearson's Chi-square test; **Fisher's exact test. 
result, as only $25.7 \%$ of the older adults would stay online for more than two hours. In other regions of the country, $40 \%$ or more of the older adults stayed online for more than two hours.

In addition, bivariate analysis between the predictor variable occupation and some outcome variables showed statistically significant association between the variables daily Internet access $(p=0.002)$ and answering health questions on the internet $(p=0.01)$, which were respectively $34 \%(P R=1.34 ; 95 \% \mathrm{Cl}: 1.18-1.53)$ and $21 \%(\mathrm{PR}=1.21 ; 95 \% \mathrm{Cl}: 1.06-1.38)$ more frequent among older adults who worked. Similarly, there was a statistically significant association $(p=0.01)$ between the variable civil status and the time spent online. Accessing the Internet more than once a day was 30\% more frequent among older adults who did not have a partner ( $P R=1.30-95 \% \mathrm{Cl}$ : 1.15-1.46).

In addition, statistically significant differences were also identified between age and daily internet access, time spent online and the following benefits: autonomy, independence, and interaction. Older adults who used the internet daily (average rank $64 \mathrm{vs.} 66 ; p=0.01$ ) and for more than 2 hours (average posts 62 vs. $65 ; p=0.004$ ) were the youngest. Similarly, autonomy and independence were more often seen as a benefit by the young-old (average rank 61 vs. 64, $\mathrm{p}<0.001)$. In contrast, interaction was most often pointed out as a benefit by the older participants (average rank 65 vs. $62, \mathrm{p}<0.001$ ).

\section{DISCUSSION}

This study describes the use of the internet among Brazilian older adults, especially those who use the social networks Facebook and WhatsApp via cell phones, given that there is a greater number of older adults who use the internet by other means. Because of the success and adherence to these social networks, an unprecedented scale of social relationships diffuses across this vastly interconnected system, affecting public behavior and knowledge construction ${ }^{(11)}$. It is understood that both men and women use these technological tools in their daily lives, so there was practically no difference between the number of women and men in this investigation, although studies demonstrate that they use these tools with different purposes ${ }^{(12-13)}$.

The use of cell phones as the main means of internet access by older adults can be explained by the advantages of portable devices, as they can be used anywhere, are easy to use, are less complex than other interfaces and do not require any wires. In addition, the financial cost of this technology is lower compared to other devices and it provides the convenience of accessing the internet in your own home. ${ }^{(14)}$.

In relation to the regions of Brazil where the older adults lived, it was observed that there were statistically significant differences regarding the sources of information, level of education and internet access, and the minority of participants were in the North and Center-West regions. The difference in the number of older adults who use the internet by region may be directly related to social and educational conditions or, still, to population density.

According to the Continuous National Household Sample Survey ${ }^{(15)}$, the Southeast region had the highest percentage $(81.1 \%)$ of households with internet access, followed by the South $(76.7 \%)$ and Northeast (64\%) regions. Despite this rate and the fact that most older adults in the Southeast have a higher education level, the television is their preferred source of information according to the results of this study.

It is worth mentioning that $85 \%$ of the sample was composed of older people under 68 years of age, who are considered youngold $^{(16)}$. In this context, it was found that older adults who used the internet every day and for more than 2 hours were younger than the others and pointed to autonomy and independence as benefits of the internet more often. Researchers report that the young-old have the ability to be more active in society, with preserved functional capacity and with an interest in expanding their possibilities in the human, social and educational fields, with the goal of learning ${ }^{(17)}$.

In the sample of young-old adults in this study, it was found that about $32 \%$ of the participants were still working, and that those participants accessed the internet and answered their health doubts more frequently than those who were retired. This can possibly be explained by the fact that they use these technologies in work activities and/or were already familiar with digital tools ${ }^{(18)}$.

However, the internet is rarely used for work purposes among older adults, as the primary motivations for using social networks usually involve social bonding, bridging, curiosity and responding to family members request $s^{(19)}$. In addition, a study revealed that older adults use Information and Communication Technologies (ICTs) to find information and because of the need and desire to communicate with others and to be entertained ${ }^{(20)}$. This result was confirmed in this study, as the main activities of the older adults on the internet were reading, listening to music, playing games, watching videos and photos; talking to people; meeting new people and/or seeking a romantic relationship; research and study; and accessing social networks.

The use of ICTs for teaching and learning purposes is still a challenge for older adults. In this sense, a recent study investigated how this population view its own digital skills, the barriers experienced and the social and institutional support system that help gaining digital literacy, and found that older adults do not have digital literacy and support systems are limited ${ }^{(21)}$. The barriers faced may be linked to the level of education, although it has been found that this is not necessarily a limitation. In this study, it was found that the level of education did not prevent older adults from enjoying the internet, since two participants were illiterate and 15 had only elementary education, which demonstrates the importance of motivation for human beings.

With the finding that $65 \%$ of the participants used the internet to solve health concerns and considering the importance of health promotion through ICTs, four important aspects of an ICT for older adults can be pointed out: usefulness of learning (responding to the personal and social needs of older adults), cooperation and collaboration (focusing on teamwork, support, cohesion and interaction to achieve more proactive learning), promoting social inclusion and autonomy (being protagonists in their own learning) ${ }^{(14)}$. These points converge to the benefits most cited by the participants in this study: interaction, pointed out by $75 \%$ of the sample and more often by those who were older, followed by learning and updating, pointed out by a quarter of the sample.

As for the benefits listed, interaction was the most prevalent and entertainment, learning and updating were associated with 
gender, with the first two being most pointed out by women. In addition, women usually spend more time online according to this study. The difference observed may be related to individual characteristics, such as motivations for use, personality, selfesteem and time of use. Social networks are recreational and public and thus are associated with a greater inclination towards social activity and relationships and a tendency to find, interact with and share information with other users ${ }^{(24-25)}$.

Almost all older adults in this study accessed the internet every day, and more than once a day. This frequency of access was $30 \%$ more frequent among older adults who had no partner. In this sense, the study identified that the use of digital technologies enables older adults to seek relationships, resulting in a reduction in feelings of loneliness and abandonment and becoming a tool in the search for companionship. In this context, emotional involvement is understood as the most relevant feeling mentioned by the elderly ${ }^{(26)}$.

However, it is necessary to recognize that, with increase of internet use for this purpose, older adults become vulnerable to digital abuse in romantic relationships, a phenomenon internationally known by the term Cyber Dating Abuse ${ }^{(27)}$. This phenomenon includes threats, insults, humiliations or jealous behavior, partner controlling behavior (such as requiring passwords from cell phones or e-mail accounts), sharing photos or videos of a partner without their permission, pressuring a partner to send sexually explicit photos or videos or to engage in sexual acts against their will through the internet or cell phone ${ }^{(27-29)}$. Scholars claim that, on one hand, digital abuse emerges from violence between intimate partners, and, on the other, it is closely related to the development of communication technologies and their insertion in the social environment ${ }^{(30)}$.

Therefore, it is important that health professionals are attentive to the sexual dimension of the older adults' life, especially in the digital age, when this population expanded their possibilities of satisfying sexual needs and desires. However, understanding how older adults think and feel about their sexuality is necessary not only to understand the aging process and sexuality, but to identify and develop strategies that minimize the effects of senescence on sexuality, contributing to a positive and healthy experience. This depends on professional follow-up free of prejudice, taboo and, above all, of criticism ${ }^{(31-32)}$.

The use of the internet among older adults has been a major concern in the search for a more inclusive society, with the objective of solving the demands related to aging process and the various changes in digital and communication technologies ${ }^{(33-35)}$. Therefore, the Internet can favor social inclusion among older adults, as it can provide more effective communication between family and friends and increase the possibilities of updating, learning, interaction, and others.

The internet can insert older adults in the contemporary social world, bringing new perspectives for social interactions. The relevance of accessing, using and learning about technological resources in the context of aging can be highlighted. One of the goals of healthy aging is to continue learning to adapt to the changes of the aging process and to acquire skills to remain active and productive. In this sense, it is believed that the Internet use among older adults can favor this objective ${ }^{(36)}$.

\section{Study limitations}

The cross-sectional design of the study can be considered a limitation, as it does not allow for causal inference. However, the national coverage and the target audience minimized this effect. In addition, the inclusion criterion of older adults who used two social networks and the difficulty to get in closed Facebook groups were characterized as limitations.

Therefore, new studies with mixed approaches should be carried out to get a deep understanding of the universe of internet use among older adults, including data such as shared information, most accessed links and social and health repercussions after using the internet. In addition, it is necessary to develop studies that can clarify the verified associations and contribute to the discussion of the theme in nursing, since nurses must provide care to older adults considering all human needs, including the use of technologies as a means of providing health.

\section{Contributions to the nursing area}

In the health area, especially in nursing, the existing technologies must be combined to promote health. Nurses have a significant role in the assistance to older adults, as they are the closest to this population. Thus, the use of the internet by nurses and older adults can enable a more effective assistance, since it contributes to faster and more dynamic monitoring and guidance ${ }^{(34)}$.

Therefore, nurses need to understand technologies and Internet use to offer multiple perspectives on the expansion of information for this population, favoring and enabling interaction and collective construction of knowledge. In addition, these professionals need to provide opportunities for improving the quality of life of this population, so that social and health repercussions can be provided to older adults in an appropriate and safe way.

From this perspective, based on the findings of this study, health professionals are able to provide assistance, develop prevention and health promotion actions and create public policies to include older adults in society through the use of the powerful tool of the internet as support in health.

The use of data from this research can support the improvement of health professionals in digital and information technologies and communication, providing countless possibilities of using this tool as a means of reaching older adults. In this sense, the internet can influence health behaviors and become an efficient tool for health promotion in the targeted population.

\section{CONCLUSION}

This study showed the main characteristics of Brazilian older adults who use the internet, more specifically through the social networks Facebook and WhatsApp, making it possible to recognize the possibilities of health care strategies in the virtual space. Brazilian older adults who use the internet through these social media had a mean age of 64.60 years, were predominantly married, retired, with secondary level of education and from the Southeast, Northeast or South regions. They used the Internet predominantly via cell phone and to perform activities such as reading, listening to music, watching videos and photos, playing 
games, talking and meeting new people and/or seeking a romantic relationship. It was noticed that health information is a potential focus of interest for these older adults when they browse the internet and social media, since $65 \%$ of the participants said they used the internet to answer questions about health care. There was a statistically significant difference between the different Brazilian regions and the variables related to the sources of information, level of education, daily internet access and time spent online. The bivariate analysis between occupation and the variables daily internet access and solving health concerns on the internet showed a statistically significant association. Similarly, the association between civil status and frequency of internet access revealed that accessing the Internet more than once a day is a behavior $30 \%$ more frequent among older adults without a partner.

In addition, there were also statistically significant differences between age and daily internet access, time spent online and the following benefits: autonomy, independence, and interaction.

\section{REFERENCES}

1. Instituto Brasileiro de Geografia e Estatística (IBGE). Projeção da População 2018: número de habitantes do país deve parar de crescer em 2047[Internet]. Estatísticas Sociais; 2018 [cited 2019 Nov 10]. Available from: https://agenciadenoticias.ibge.gov.br/agencia-sala-deimprensa/2013-agencia-de-noticias/releases/21837-projecao-da-populacao-2018-numero-de-habitantes-do-pais-deve-parar-de-crescerem-2047

2. Hong Y, Cho J. Has the digital health divide widened? trends of health related internet use among older adults from 2003 to 2011 . J Gerontol B Psychol Sci Soc Sci. 2017;72(suppl 5):856-63. doi: 10.1093/geronb/gbw100

3. Comitê Gestor da internet no Brasil. Pesquisa sobre o uso das tecnologias da informação e comunicação no Brasil - TIC Domicílios e TIC Empresas 2013. São Paulo: CGI.br [Internet]. 2014 [cited 2019 Sep 19]. Available from: http://www.cetic.br/media/docs/publicacoes/2/ TIC_DOM_EMP_2013_livro_eletronico.pdf

4. Zhou J. Let us Meet Online! examining the factors influencing older chinese's social networking site use. J Cross Cult Gerontol [Internet]. 2019 [cited 2019 Nov 10];34(1):35-49. Available from: https://pesquisa.bvsalud.org/portal/resource/pt/mdl-30793217

5. Confortin SC, Schneider IJC, Antes DL, Cembranel, Ono LM, Marques LP, et al. Living conditions and health of the elderly: results of the EpiFloripa Idoso cohort study. Epidemiol Serv Saúde. 2017;26(2):305-317. doi: 10.5123/s1679-49742017000200008

6. Heinz M, Martin P, Margrett JA, Yearns M., Franke W, Yang HI., et al. Perceptions of technology among older adults. J Gerontol Nurs. 2013;39(1):42-51. doi: 10.3928/00989134-20121204-04

7. Carlotto IN, Dinis M AP. Bioethics and promotion of teacher health in higher education: an interface required. Saber Educar [Internet]. 2017 [cited 2029 Nov 10];23:168-179. Available from: http://revista.esepf.pt/index.php/sabereducar/article/view/291

8. Malta M, Cardoso LO, Bastos FI, Magnanini MMF, Silva CMFP. Iniciativa STROBE: subsídios para a comunicação de estudos observacionais. Rev Saúde Pública [Internet]. 2010 [cited 2020 Jul 02];44( 3):559-565. doi: 10.1590/S0034-89102010000300021

9. Baldin N, Munhoz EMB. Educação ambiental comunitária: uma experiência com a técnica de pesquisa snowball (bola de neve). REMEA [Internet]. 2011 [cited 2019 Dec 14];27: 46-60. Available from: https://periodicos.furg.br/remea/article/view/3193

10. Aragão JMN, Gubert FA, Torres RAM, Silva ASR, Vieira NFC. The use of Facebook in health education: perceptions of adolescent students. Rev Bras Enferm. 2018;71(suppl-2):265-71. doi: 10.1590/0034-7167-2016-0604

11. Sapountzi A, Psannis KE. Social networking data analysis tools \& challenges. Future Gener Comput Syst. 2018;86:893-913. doi: 10.1016/j. future.2016.10.019

12. Krasnova H, Veltri NF, Eling N, Buxmann P. Why men and women continue to use social networking sites: the role of gender differences. J Strategic Inf Syst. 2017;26(4). doi:10.1016/j.jsis.2017.01.004

13. Khalaila R, Vitman-Schorr A. Internet use, social networks, loneliness, and quality of life among adults aged 50 and older: mediating and moderating effects. Qual Life Res. 2017;27(suppl 2), 479-89. doi:10.1007/s11136-017-1749-4

14. Amorim DNP, Sampaio LVP, Carvalho GA, Vilaça KHC. Aplicativos móveis para a saúde e o cuidado de idosos. RECIIS. 2018;12(suppl 1):58-71. doi: $10.29397 /$ reciis.v12i1.1365

15. Instituto Brasileiro de Geografia e Estatística (IBGE). Acesso à internet e a televisão e posso de telefone móvel celular pra uso pessoal. Diretoria de Pesquisas, Coordenação de Trabalho [Internet]. 2018[cited 2020 Jan 05]. Available from: https://biblioteca.ibge.gov.br/ visualizacao/livros/liv101631_informativo.pdf.

16. Navarro JHN, Andrade FP, Paiva TS, Silva DO, Gessinger CF, Bos AJG. The perception of the young and long-lived elderly 'Gauchos' (from the State of Rio Grande do Sul, Brazil) about the public spaces they live in. Ciênc Saúde Colet [Internet]. 2015 [cited 2020 Jan 05];20(2):461-70. Available from: http://www.scielo.br/pdf/csc/v20n2/1413-8123-csc-20-02-0461.pdf

17. Schlomann A, Seifert A, Zank S, Woopen C, Rietz C. Use of Information and Communication Technology (ICT) devices among the oldest-old: loneliness, anomie, and autonomy. Innov Aging. 2020;4(suppl 2). doi:10.1093/geroni/igz050

18. Jung EH, Sundar SS. Senior citizens on Facebook: how do they interact and why?. Comput Hum. Behav. 2016;61:27-35. doi: 10.1016/j. chb.2016.02.080 
19. Castellacci F, Viñas-Bardolet C. Internet use and job satisfaction. Comput Hum Behav. 2018. doi: 10.1016/j.chb.2018.09.001

20. Fernandez MDM, Hernández JDS, Gutiérrez JM, Escuela MRH, Fino ER. Using communication and visualization technologies with senior citizens to facilitate cultural access and self-improvement. Comput Hum Behav. 2017;66:329-344. doi: 10.1016/j.chb.2016.10.001

21. Schreurs K, Quan-Haase A, Martin K. Problematizing the digital literacy paradox in the context of older adults' ICT use: aging, media discourse, and self-determination. Can J Commun. 2017;42. doi: 10.22230/cjc.2017v42n2a3130

22. Dhir A, Torsheim, T. Age and gender differences in photo tagging gratifications. Comput Hum Behav. 2016;63:630-8. doi: 10.1016/j. chb.2016.05.044

23. Marino C, Gini G, Vieno A, Spada MM. A comprehensive meta-analysis on Problematic Facebook Use. Comput Hum Behav. 2018;83:262-77. doi: 10.1016/j.chb.2018.02.009

24. Luciano ACL. Redes virtuais: uma alternativa à solidão? relacionamentos na velhice. Rev Portal Divulg [Internet]. 2018 [cited 2020 Feb 03];56:5-10. Available from: http://www.portaldoenvelhecimento.com/revistanova/index.php/revistaportal/article/view/709/772

25. Cavalcanti JG, Coutinho MPL. Cyber Dating Abuse: a review of prevalence, evaluation instruments and risk factors. Av Psicol LatinoAm. 2019;37(suppl-2):235-54. doi: 10.12804/revistas.urosario.edu.co/apl/a.6888

26. Borrajo E, Gámez-Guadix M., Pereda N, Calvete E. The development and validation of the cyber dating abuse questionnaire among young couples. Comput Hum Behav. 2015;48:358-65. doi: 10.1016/j.chb.2015.01.063

27. Ouytsel J, Ponnet K, Walrave M. Cyber dating abuse: Investigating digital monitoring behaviors among adolescents from a social learning perspective. J Interpers Violence. 2017;35(23-24). doi: 10.1177/0886260517719538

28. Flach RMD, Deslandes SF. Digital abuse in affective-sexual relationships: a bibliographic analysis. Cad Saúde Pública. 2017:33(suppl 7). doi: 10.15090/0102-311×00138516

29. Evangelista AR, Moreira ACA, Freitas CASL, Val DR, Diniz JL, Azevedo SGV. Sexuality in old age: knowledge/attitude of nurses of Family Health Strategy. Rev Esc Enferm USP. 2019;53. doi: 10.1590/S1980-220X2018018103482

30. Souza CL, Gomes VS, Silva RL, Silva ES, Alves JP, Santos NR, et al . Aging, sexuality and nursing care: the elderly woman's look. Rev Bras Enferm [Internet]. 2019 [cited 2020 Mar 22];72(2):71-8. doi: 10.1590/0034-7167-2018-0015

31. Manso MEG, Roth MC, Lopes RGC. Idosos vivenciando o diabetes nas redes sociais. Rev Portal Divulg [Internet]. 2017 [cited 2020 Jan 05];53:63-8. Available from: https://www.portaldoenvelhecimento.com/revistanova/index.php/revistaportal/article/viewFile/681/750

32. Santos PA, Heidemann ITSB, Marçal CCB, Arakawa-Belaunde AM . A percepção do idoso sobre a comunicação no processo de envelhecimento. Audiol Commun Res [Internet]. 2019 [cited 2020 Feb 03];24. doi: 10.1590/2317-6431-2018-2058

33. Boekel LC, Peek STM, Luijkx, KG. Diversity in the use of older adults on the Internet: identifying subgroups through latent class analysis. J Med Internet Res. 2017;19 (suppl 5). doi: 10.2196/jmir.6853

34. Sá GGM, Silva FL, Santos AMR, Nolêto JS, Gouveia MTO, Nogueira LT. Tecnologias desenvolvidas para a educação em saúde de idosos na comunidade: revisão integrativa da literatura. Rev Latino-Am Enferm [Internet]. 2019 [cited 2020 Mar 11];27:3186. doi: $10.1590 / 1518-8345.3171 .3186$ 